\title{
Ageing and Dying Radically
}

\section{Andrew Dawson}

\begin{abstract}
Aвstract: This biographical and, in part, phenomenological anthropology of older people in post-industrial England illuminates a local and generationally specific communitarian critique of and form of resistance against the process of individualisation. Rather than presenting communitarianism conventionally as an abstract political ideology or set of ideas about locality, it is conceptualised as emerging from and being reinforced by experiences of ageing, especially bodily ageing. It these respects, the article responds positively to Tatjana Thelen and Cati Coe's call to take the anthropology of ageing out of its current condition of relative intellectual marginality, by recognising ageing and its related care arrangements as key structuring features within societies and political organisation and by treating them as a window onto understanding broad-scale social and political processes.
\end{abstract}

KeYwords: ageing, care, death, dementia, ethnography of Britain, gerontology, individualisation

In a recent and, I would argue, path-breaking article, Tatjana Thelen and Cati Coe (2017) take issue with the anthropology of ageing. Once a central aspect of the discipline's study of social organisation (especially with regard to what were known as 'age-grade societies'), the study of ageing has more recently tended to self-marginalise, especially in the sense of failing to appreciate ageing's broader social and political significances.

The roots of anthropology's 'de-politicisation' of ageing are, according to Thelen and Coe, two-fold. First, reflecting a widespread view that modernisation strips older people of many of the kinds of powers they might once have held in 'traditional' societies, many anthropologists have tacitly endorsed a cultural imagination of older persons as passive, stable and norm-conforming. Second, and following a lead from the earliest versions of gender studies and childhood studies, attention has focussed largely on documenting the diversity of ageing experiences rather than appreciating age as a key structuring feature within societies and political organisation.

Thelen and Coe are two amongst a growing number of anthropologists researching care practices (see, for example, Alber and Drotbohm 2015; Buch 2013;
Dawson and Goodwin-Hawkins 2018a), whose primary concern is with elder care. Without wishing to rehearse their analysis in detail, I want to stress their point about how ageing and its associated care arrangements are generative of political belonging and change. As such, they advocate a focus on elder care as a key window onto understanding broad-scale social and political processes. Echoing their distaste for the anthropology of ageing's erstwhile narrow concern with appreciating diversity, the particular utility they detect in elder care in regard to understanding broad-scale social and political processes is that it 'collapses domains that are usually kept artificially separated' (Thelen and Coe 2017: 1), especially kinship and the state, and private and public.

This article takes up Thelen and Coe's call to recognise ageing and its related care arrangements as key structuring features within societies and political organisation and to treat them as a window onto understanding broad-scale social and political processes. In particular, it concerns itself with a process that has been ubiquitous in Western and other societies in the late twentieth and early twenty-first centuries - 'individualisation' (see, for example, Dawson 2012). Individualisation has an oxymoronic quality,

Anthropology in Action, 25, no. 3 (Winter 2018): 23-33 @ Berghahn Books and the Association for Anthropology in Action ISSN 0967-201X (Print) ISSN 1752-2285 (Online) doi:10.3167/aia.2018.250303 
the dimensions of which have been explored voluminously, including in relation to the issue of ageing. Anthony Giddens (1991), on the one hand, explores the inexorable expansion of choice available to us in reflexively fashioning selfhood. In this respect, an array of issues has been explored in relation to ageing. These include the choices available to individuals as they near death regarding funerary practices (Arnold et al. 2018). On the other hand, Ulrich Beck and Elisabeth Beck-Gernsheim (2002) highlight how individuals are increasingly compelled to make agonistic choices and to take sole responsibility for them. This observation has made for a range of studies that consider 'responsibilisation' in ageing, including for self-care (Rudman 2015). This issue is commonly explored in relation to the rise of neoliberalism (Collins et al. 2015).

I highlight funerary practices and responsibilisation because they are matters that appear in the data which informs this article. However, my concern is less with manifestations of individualisation than with the responses of older people to that individualisation. I identify a commonplace and counterhegemonic response to individualisation in ageing amongst the older residents of the former coal-mining town of Ashington in north-east England that is the ethnographic focus of this article (see also Latimer on 'Repelling Neoliberal World-Making' 2018). Against individualisation, this counter-hegemonic response is, in essence, a kind of native communitarianism - a belief that a person's identity and (at least beyond the family) obligations are determined by community relationships, especially those within a given place (Dawson 1998; Etzioni 1996).

In important ways, this native communitarianism connects to deep-seated cultural ideals concerning the nature of locality and to other national political ideologies, especially labourism (see below). However, more than demonstrating this, or, indeed, the content of the phenomenon of communitarianism, the central purpose of the article is to show how this native communitarianism, and, by dint, localism and labourism (albeit to a much lesser extent - see below), emerges and is transformed by the very experience of ageing itself.

Empirically, the article is, in essence, a biographical anthropology of one local woman's later life experiences. The woman in question is Elizabeth Ord, ${ }^{1}$ who I first came to know in 1985 at the inception of my life's research project on ageing and post-industrialism (Dawson 2010). I remained close to Elizabeth throughout the later years of her life until her death in 2012, following several years in which she had suffered from dementia.
The article unfolds through four short essays (see also, Dawson 2017) on different aspects of ageing friendships, illness, remaining in social connection, and resisting social disconnection. Furthermore, each of these four short essays utilises or addresses in small ways different anthropological thematics that, in practice, rarely intersect and, in some cases, have rarely been brought to bear in the anthropological understanding of ageing. They are the anthropological study of post-Fordist affect; anthropological phenomenology; the anthropological study of dementia; and the anthropology of death. In this way, and in that in general I explore the relations that ageing has with individualisation and neoliberalism and, indeed, communitarianism, localism and labourism (topics more conventionally explored in political anthropology), I respond to Thelen and Coe's call to collapse domains of anthropological enquiry that are usually kept artificially separated. The central argument that I develop through the article connecting the four short essays is that ageing, in this context at least, is experienced as entailing an inexorable movement of the self from containment in the individual body to become communally merged with the selves of others. This, in turn, provides a phenomenological grounding for communitarianism and a critique of and resistance to individualisation.

\section{Background: Context and Method}

\section{Ashington}

The Northumbrian conurbation of Ashington comprises a town that goes by that name and a number of surrounding villages. The inception of Ashington as a settlement of significant size can be traced back to the late stages of the Industrial Revolution, when it emerged as a centre for coal-mining. In time, the mines came to be by far the biggest local employers, and most other local businesses relied on the trade they generated. However, through Britain's transformation from a predominantly industrial economy to a service economy, the mining industry went into steep decline from the mid-1960s and Ashington's last mine eventually closed in 1994.

Facing no obvious alternative source of major employment, Ashington, in general, went into a sharp economic decline in the later part of the twentieth century. This situation has been ameliorated, only slightly, by the developments of small light industrial and service sectors and by low-cost private accommodation (built upon the 'brownfield' expanse left by mining) for working-class commuters priced 
out of the housing market in the nearby city of Newcastle-upon-Tyne. Contemporarily, Ashington is characterised by high levels of unemployment and outmigration. Its current population is roughly 22,000 , and it is rapidly ageing.

Nevertheless, despite its post-industrial transformation, Ashington has retained its identity as a singleindustry town. For example, the town's local museum still describes it as 'the biggest mining village in the world'. Importantly, mining remains an essential referent for how local people frame who they are and what they do and think, including their conceptualisations of communitarianism, localism, labourism, neoliberalism and individualisation.

\section{Communitarianism, Localism, Labourism,}

Neoliberalism and Individualisation

Characterised by practices of mutual aid that are seen as responses to specific forms of hardship engendered by its development as a mining conurbation, Ashington's communitarianism is commonly represented as the very essence of locality. This feature marks it off as distinctive from other local conurbations, including in narratives articulated by local press, amateur history and the town's heritage museum (Dawson 1998). In contrast, Ashington's local communitarianism often sits uneasily with another locally widespread ideology - labourism. Defined broadly as an adherence to regulation of the economy, nationalisation of industry, Keynesian economic management and, crucially, a strong welfare state, ${ }^{2}$ labourism presents the obligation to provide aid as resting principally with the state rather than with the members of communities. Nonetheless, communitarianism, localism and labourism meet in a shared antipathy towards individualisation, and especially the individual responsibilisation wrought by neoliberalism. ${ }^{3}$ Neoliberalism took root in Britain following the election of the Conservative Thatcher government in 1979 and has persisted even through the election of Labour governments, since, by and large, the Labour Party has abandoned labourism itself (Evans 2012). As an aside, it is also worth pointing out that amongst local older people communitarian values are often seen as the preserve of older generations and as lacking in younger generations largely because of the timing of this historic shift. The generational schism is so marked that generational differences are often attributed quasi-ethnic dimensions (Dawson 2018a; Dawson 2018b).

\section{Biographical Anthropology}

Research for the article was generally carried out in the conventional ways of anthropology - 'an approach to social and cultural research involving long-term immersion in research contexts and the deployment of a range of methodological strategies and techniques selected by the researcher as she deems them to be contextually and interpersonally appropriate, but in which participant observation predominates' (Goodwin-Hawkins and Dawson 2018: 270). However, the article is perhaps unusual in its focus on the life of one informant only.

This is not merely a pragmatic strategy designed to present the kind of detailed and intimate data that biographical approaches afford (Miller and Brewer 2003). Rather, my approach resonates with other anthropological accounts that explore broad-scale processes as they are manifested intimately within one or a few lives (see, for example, Shostak 1981). Furthermore, the biographical approach that I adopt takes its lead from the psychoanalytic anthropology of George Devereux (1978). He argues that to generalise by averaging large numbers of individuals' traits or by seeking common denominators or representativeness is to corrupt identity. In contrast, he recommends that anthropology involve appreciating how humanity is to be found in the one human being (Nigel J. Rapport, personal correspondence 2015). In the later-life history of Elizabeth Ord, I see resonances with the experiences of ageing in Ashington generally.

\section{Essay 1 - Friendship (the Anthropology of Post-Fordist Affect)}

A high achiever at school, Elizabeth Ord had gone on to secretarial college and, then, a long-term position as a clerical officer in local government. Then, after the last of her children went to school in the early 1960s, she took advantage of a government scheme designed to ameliorate the shortage of teachers at the time. She fast tracked into a local teaching job via study for A-levels ${ }^{4}$ and obtaining a teaching diploma.

Despite her new standing as a 'professional', Elizabeth resisted most of the trappings of upward mobility. Though she moved from the colliery rows to a 'nicer part of town', her friendship network cohered the wives of the coal-mining men with whom her husband Eric had worked as an engineer at a local colliery. Elizabeth regarded these friendships as unbreakable and involving deep senses of mutual obligation. Indeed, as the only one of the group to enjoy a regular income during The Miner's Strike of 1983-1984, Elizabeth had discreetly subsidised each of her best friends, Miriam (Eric's sister), and Minnie and Ruth - 'The Girls', as they referred to one another 
collectively. In this context, where the working-class culture of 'respect' (Williamson 1982) is paramount, the others admired her all the more for maintaining the 'public secret' (Taussig 1999) of their status as recipients of charity.

The solidarism of Britain's coal-mining communities that is manifested especially in their high strike propensity relative to other industrial communities is commonly attributed by industrial sociologists to various structural factors, such as their concentrated forms of residential settlement, the non-seasonality of mining work and limited access to transferable skills (Bulmer 1975). However, whilst such structural factors are important, local older people in Ashington highlight as paramount the particular organisation of production in coal-mining in accounting for the nature of their social relations.

Commonly, mining was conducted by teams of men, the different members of which had different skill sets. Importantly, team membership tended to endure, often for many years. Famously, Antonio Gramsci observed that contexts of production in advanced capitalism have transformed to a generalised system of social organisation characterised by 'a specific mode of living and of thinking and feeling life' (1997: 302). Taking Gramsci's insight further, several scholars have persuasively argued that capitalism's social relations of production have the capacities to frame structures of affect (Berlant 2007). Furthermore, those structures of affect may extend beyond the social groups that were directly affected by them (Allison 2012) and endure through time as 'afterlives' long after the productive forms upon which they were based have terminated (Muehlebach and Shoshan 2012: 317).

Still today, in the post-retirement present of their husbands, women like Miriam, Minnie and Ruth account for the solidity of their bonds of friendship in terms of the often-indescribable feelings wrought by the organisation of production in mining. Sometimes, these are feelings of unbridled joy. When in short supply, the teams of men competed with one another for work. Many local people argue that failure in this respect lies at the root of Ashington's systems of mutual aid and that success in this respect lies at the root of its celebrated bacchanalian forms of socialising. Sometimes, and more commonly, these are feelings of anxiety. Similar to others of their kind, a defining experience in the lives of these women is that they had faced fear together wrought by the ever-present threat of mining accident and death and the loss of loved ones (Dawson 2000).

\section{Essay 2 - Illness (Anthropological Phenomenology)}

As Elizabeth, Miriam, Minnie and Ruth aged together, their meeting places changed so that they could 'get from under the feet' of their then retired and largely house-bound husbands. At first, they met in the women-only snug rooms of the local 'working men's clubs'. Then, as they got older and laws against sexual segregation solidified into practice, they moved on to meeting almost daily in a few of the local Darby and Joan and Over-65s clubs. Next to other groups of mostly women who were much like themselves, The Girls sat together as a foursome to enjoy club concert parties, collective bingo sessions and more intimate rounds of cards, dominos and the word-based game Scrabble. They also talked a lot. Very much at ease in the clubs, the frequency of their visits grew over the years.

As years passed, conversation turned increasingly to a major preoccupation in their lives - physiological ageing with its illnesses, pains and worries; medical appointments; and visits to pharmacists. Nevertheless, 'whinging' amongst these four women, and indeed amongst club members in general, was barely tolerated. Rather, ageing tended to be met with public displays of stoicism and self-deprecatory humour. Researched by my colleague Bryonny GoodwinHawkins (Dawson and Goodwin-Hawkins 2018b), a song sung in other northern English clubs for older people captures the phenomenon in its most gentle form. Set to the tune of Rodgers and Hammerstein's 'My Favourite Things', it runs as follows:

Back pains, confused brains and no fear of sinning, Thin bones and fractures and hair that is thinning, And, we won't mention our short, shrunken frames, When we remember our favourite things.

In post-coal-mining Ashington, the stoicism and selfdeprecatory humour often take a more brutal form. For example, the undoubted star performance in one of the club's concert parties was an older man's rendition of Eddie Cochran's rock and roll classic, 'Shaking All Over', complete with quiff wig and wild body movements. It was certainly no coincidence that the performer had recently been diagnosed with Parkinson's. And, generally, in an embracing of their relatively impending deaths the participants chose The Talking Heads' 'We're on the Road to Nowhere', rather than the anodyne Darby and Joan club closing song.

A further manifestation of said stoicism is, perhaps, also the manner in which people came through 
physiological ageing to speak about their selves in relation to their bodies (including their minds), with use of the first person - 'me' - to spell the self and the use of the third person - 'it' for the body as a whole and 'it' or 'them' ('bloody legs', etc.) for body parts to spell the body (Dawson 2002: 26-28). Sometimes, the phenomenon had a temporal dimension. For example, throughout the rapid cognitive decline that she experienced late in her life, Elizabeth and her friends would not simply talk about 'this/that mind of mine/hers', they would also come increasingly to speak of 'me'/'Elizabeth' (i.e. herself), even in the present day, in terms of characteristics that could only reasonably be said to describe her in the past. For example, even though Elizabeth lost the ability to play Scrabble, the other Girls continued to describe this former English teacher as being 'quite the wordsmith'. Sometimes, the phenomenon has a spatial dimension. For example, helping new club participants in 'getting to know' Elizabeth consisted less of an invitation to discourse and more of a showing and narrating by others of the many photographs that she always kept in her handbag, especially in the very advanced stages of her cognitive decline, when she became an increasingly silent and passive presence. It was as though Elizabeth (i.e. herself) resided less in the form of her body and more in her material, social and reproductive life achievements presented in the images, such as her posh private estate home, her graduation day and her children and grandchildren.

In The Absent Body (1990), phenomenologist Drew Leder describes everyday life experience in conditions of physiological wellness entailing the body's 'disappearance' from consciousness. Contrastingly, conditions of illness entail the body's 'dys-appearance' in consciousness. The spelling of body through physiological ageing in the third person certainly reflects the experience of bodily dys-appearance - or in other words, bodily absence or alienation - that Leder describes. However, more than this, it reflects how through physiological ageing the self may be experienced as partable from the body, in the sense that selfhood is experienced as temporally and spatially transgressive. In other words, the self can be experienced as residing elsewhere than in the body with which it had been principally associated. This may, indeed, be reflected etymologically in terms so commonly associated with physiological ageing 'incontinence', whereby one's body becomes uncontained - and in regard to extreme forms of cognitive decline - 'bewilderment', whereby one's being or self goes wild.

\section{Essay 3 - Remaining in Social Connection (the Anthropological Study of Dementia)}

The onset of Elizabeth's cognitive decline seemed to have come suddenly. During a short city break in Paris, she was mugged. In retrospect, her husband Eric thought the wooziness that he had witnessed in her at the time had been a minor stroke. There followed a long period of depression and then, in turn, inexorable cognitive decline. It began with the simplest of things, like Elizabeth forgetting how to perform household tasks properly, such as timing a meal, through to a near total inability to instantly recognise the very surroundings that she had inhabited for most of her life as she came closer to death 10 years later. Everybody could see this in the look of frightened surprise that she gave when moving from one room to another in the clubs and even at home. Though everybody denied it at first, but came to realise it later, Elizabeth was never diagnosed with dementia. Reflecting the labourism typical of this area, Miriam was certain of the reason. Diagnosis would have meant expensive treatment, 'a definite no-can-do in the cost-cutting Tory ${ }^{5}$ NHS' (National Health Service), she said.

Thankfully, the world's apparent growing unfamiliarity to Elizabeth never seemed to extend to those closest to her: her husband Eric and their children, but also Miriam, Minnie and Ruth (though Elizabeth would often forget or mix up their names). Indeed, her reliance and demonstrable love and affection for the other Girls seemed to grow in inverse relation to her cognitive decline. In return, the increasing frequency with which Miriam, Minnie and Ruth now 'took' Elizabeth to the clubs (in the manner of assuming the role of carers) was less an expression of concern in giving Eric carer respite than a reflection of their determination to keep Elizabeth in ever closer connection.

Historically, the most significant transformation in the conceptualisation of dementia and, relatedly, the design of its care regimes came through the rise of biomedicine (Andrews 2017). Once regarded as a normal problem of the ageing mind to be managed, dementia came to be pathologised and, hence, the subject of diagnosis, treatment and the forlorn hope of cure. This resulted in two related problems. First, since dementia confounded biomedicine's raison d'être of the cure, the 'sufferer' came to be stigmatised as a liminal being facing a 'death in life or a life in death' (Macdonald 2018). Second, attention to the sufferer's experience was progressively marginalised 
by dint of both the narrow foci on diagnosis, treatment and cure, and the stigmatisation of the patient as being less than a living being (Kleinman 2013).

This situation led, in turn, to critique of the biomedical approach and the development of 'personcentred' approaches to dementia that treated the sufferer as both an individual and social being always to be valued (Kitwood 1997). However, in practice, person-centred approaches often do little to actually value the person. Paradoxically, as Gaynor Macdonald (2018) so powerfully describes in her autoethnography of her dealings with the professionals treating her husband, the approach is grounded in the conceptualisation of dementia as consisting of an inexorable loss of personhood. Furthermore, as she illuminates, the bureaucratising 'techniques' for reconnecting with the diminishing personhood of the sufferer ensure, in fact, the very erasure of that personhood.

In contrast, recent years have seen the development of yet another significant approach to dementia and dementia care. Its central premise is that to be human is to be social - that is, to be a relational being (Macdonald 2018). The therapeutic manifestation of this is an insistence on always holding the sufferer in social connection. Conservatively, this requires an 'attentiveness' by the carer to the sufferer's individual and, as the disease progresses, rapidly altering lifeworld. In practice, for example, it might require carer attentiveness to the non-verbal modes of communication upon which some sufferers come to rely, since dementia is often characterised by progressive loss of linguistic capacity (Moser 2011). More radically, it might involve what we have described elsewhere as 'going with the flow', whereby, more than merely being attentive to the lifeworld of the sufferer, the carer actively enters into the latter's lifeworld. In practice, this may involve being prepared to indulge and participate actively in the sufferer's behaviours, regardless of how alien they may be to carers and other significant others (Dawson and Goodwin-Hawkins 2018c).

The relational approach is not widespread. That is hardly surprising. It is, in fact, currently more a best practice call than a deeply institutionalised one. It emanates partly from seminal anthropological research on dementia (e.g. Lock 2014), anthropology, and anthropology-like disciplines (Dawson and Goodwin-Hawkins 2018c; Grøn and Mattingly 2018; Macdonald 2018; Moser 2011), as one might expect given their focus on relationality. Nonetheless, it is gaining some traction. This is so because it is able to illuminate through a grounding in ethnography the profound efficacy for sufferers of their relationships with intimates, a factor often elided by expert-driven approaches offered by the likes of biomedicine.

Over time, the quality of the social connection that Elizabeth enjoyed with Miriam, Minnie and Ruth transformed. Shamefully aware perhaps of her decreasing capacity for discourse, Elizabeth became, as I have mentioned, an increasingly silent and passive presence in social gatherings. But, Miriam, Minnie and Ruth adjusted accordingly. Their communication with her was increasingly facial and tactile. However, Elizabeth's personality also seemed to change, sometimes in unexpected and destabilising ways. For example, in the decreasingly few times she spoke she began to swear a lot more and, for the first time in her life, sex became a topic of open interest for her. On good days, she flirted with men in the clubs and sometimes spoke in graphic terms about what she would like to do to them in the bedroom. Embarrassed at first, Miriam, Minnie and Ruth went on to indulge her by joining in. Furthermore, so they told me, the experience had been pleasurable and beneficial for them, as it lifted the lid on an important topic that could now be shared, despite its previously taboo status amongst these women of often austere moral upbringing. Miriam, Minnie and Ruth had gone with the flow of Elizabeth and her dementia to the benefit of both her and themselves.

\section{Essay 4 - Resisting Social Disconnection (and the Anthropology of Death)}

Despite Miriam, Minnie and Ruth's desire to keep Elizabeth in social connection, the sentiment was not always shared by others, especially managers of the clubs where the women socialised. They were places for the 'active elderly' (Wansbeck Council 1995). Though a nebulous category that echoes the broader social and political move towards responsibilisation in ageing, organisers would often point out that Elizabeth fell foul of it and so, perhaps, should be 'gently' excluded. However, and in turn, Miriam, Minnie and Ruth would also gently resist, largely by assuming Elizabeth's lost competencies. Where words and actions were required, they spoke and acted for her - to club staff, for example: 'Elizabeth would like her usual tea thank you ... strong, milky, no sugar'. Remarkably, even though it became way beyond her capacities, they continued to keep her in the rounds of cards, dominoes and Scrabble. Others took turns playing her hand and congratulating her nonetheless for the high-scoring words. And, of course, they would never fail to inform strangers 
that she 'is quite the wordsmith!' However, the 'is' in this context may be much more than an expression of Elizabeth's temporally transgressive selfhood. In light of the others now assuming her lost competencies, it may be regarded as an expression of the others coming to take guardianship of 'her self'.

The struggle over Elizabeth's presence in the clubs never came to a head, however. During a brief absence caused by a bout of chronic abdominal pain, she was taken into hospital. On Sunday, she was diagnosed with stomach cancer. Cancer had always been her greatest fear, and she had panicked uncontrollably on receiving the diagnosis. In this respect, so Eric admitted for the first time, 'her dementia' was a blessing when, 'almost as soon as she received the diagnosis she forgot it', he said. On Monday, she contracted pneumonia, and on Tuesday morning she died.

Eric was inconsolable and, frankly, incapable, having to leave all the funeral arrangements to his son David and daughter June, who drove up together from their homes in London. This ought to have been a time of peace, but, having left behind tension in the clubs with Elizabeth's passing, the remaining Girls found themselves in, albeit polite, conflict with Elizabeth's children. The source of this new tension had to do with the funeral arrangements. Born no doubt of poverty, the common tradition amongst the local mining working class had been cremation at the local Cowpen Crematorium. Cremation was followed by the scattering of the ashes in the cemetery memorial garden. The only physical memorial of the dead was a tiny plaque placed amongst many thousands of others on the sides of the paths that weave their ways through the garden. Instead, David and June had opted for burial in the graveyard of the church where the funeral was to take place. However, in what they thought was an act of peace-making with Elizabeth's friends, they consulted them on the wording and design of the headstone.

The choice of burial was offensive to Miriam, Minnie and Ruth on multiple levels. They really did not like the disrespectful faddishness. Ruth said: 'Burial in a box is bad enough, but for goodness sake an "eco-friendly wicker basket!". . . . It looked no better than what me mam carried the washing in'. The burial offended tradition. Minnie said: 'That's not the way we folk do things. Elizabeth wouldn't approve'. Also, the burial offended local ideas of class deference (see Newby 1979) in an area where the culture of respectability dictates that personal aggrandisement is as much (if not more) a sin as the inability to manage poverty (Williamson 1982). Ruth said: 'Who do they think Elizabeth is, with that private plot and big gaudy headstone? The lady of the manor? She wouldn't approve'. However, more saddening than any of the above was their being deprived of the opportunity of having all of The Girls' ashes scattered in the same place, that is, in the cemetery garden. Minnie then said, in reference to the departure from traditional practice: 'We won't be together in death. We won't become one. It's so sad. Elizabeth definitely wouldn't approve'.

In the years since Elizabeth's death, Miriam, Minnie and Ruth still talk about her daily, almost as if she was still amongst them. On one poignant occasion, Miriam bought a raffle ticket on Elizabeth's behalf and won a box of miniature brandies. On receiving the prize, Miriam took a photograph of Elizabeth from her handbag and spoke to it while laughing: 'Don't worry hinnie (a local term of endearment), we'll make good use of these for you', whereupon each of the Girls took a drink and, with reference to Elizabeth, Miriam toasted 'to absent friends'. However, Minnie interjected: 'No, no, no ... s sorry Bessie (the local diminutive for Elizabeth) my love . . . to "present" friends'. The others toasted: 'To present friends'.

Moments such as these were the ways in which the remaining Girls memorialised Elizabeth. In contrast, they almost never visited Elizabeth's grave. When I asked whether they intended to, Ruth replied, laughing: 'Oh no, that tombstone is a stupid bloody thing ... more like a memorial to the fallen martyrs of ISIS'. In reference to Elizabeth's days at secretarial college and, so they thought, rather cleverly to her roots as a coal-miner's wife and daughter, David and June had chosen Pitman shorthand for much of the headstone script. To the unaware reader, this could easily be confused with Arabic. More poignantly, Minnie replied: 'We don't need a grave to remember Elizabeth. She's here in our hearts'.

Following the seminal contribution of Robert Hertz (1960), the larger body of anthropological literature on death has considered death as a process rather than an event. The processual manner in which death is conceptualised is, by and large, seen as being about asserting social control over what is apparently a biological event (Bloch and Parry 1982). Rituals designed in this vein are commonly, though not exclusively (see, for example, Anzulović 1999) conceptualised as concerning less the transcendence of the social group than the amelioration of the crisis of existential discontinuity that death threatens, thereby guaranteeing the transcendence, or the temporal continuity, of the individual (de Beauvoir 1972). 
This is, perhaps, displayed no more clearly than in the large body of research on the 'good death'. Dying in the presence of significant others - a social death is usually recognised as a key criterion of the good death in almost all societies (Walter 2004). However, little attention has been paid to understanding the desirability and methods of maintaining social connections between the living and the dead and, indeed, the dead and other dead (Green 2008), matters that clearly are crucial to senses of appropriate funerary practice and well-being amongst women like Miriam, Minnie and Ruth.

\section{Conclusion}

In this article, I illuminated, in relation to the older residents of the former coal-mining conurbation of Ashington, the existence of what I describe as a native communitarianism, a belief that a person's identity and obligations are significantly determined by community relationships. This works as a counterhegemonic response to individualisation, a much sociologically explored and broad-scale social and political process that is intimately linked to neoliberalism, including its emphasis on responsibilisation.

Conventionally, both in the particular context of Ashington and more broadly, communitarianism has been conceptualised largely in abstraction as a political ideology (Etzioni 1996) or set of ideas about the particular nature of locality (Dawson 1998). Rather, in this article I considered how it emerges, in part, and is reinforced by the concrete experience of ageing. In this respect, I responded to Thelen and Coe's (2017) important call to recognise ageing (and its associated care arrangements) as a key structuring feature within societies and political organisation, and to treat it as a window onto understanding broad-scale social and political processes. As stated, Thelen and Coe detect a particular utility in ageing's capacity to provide such a window in that it collapses domains that are usually kept artificially separated. In this regard, they work from the meso through to the macro levels at which ageing is a matter of concern, from kin through to the state, for example. In contrast, focussing instead on how experiences of bodily ageing inform and transform lived notions of communitarianism, I work, instead, from the micro through the meso to the macro, from the body to friendships to the communitarian critique of individualisation.

My approach and findings in this regard resonate significantly with the celebrated work of phenomenological anthropologist Thomas Csordas (1990), whose life's project has been to uncover the body's role as a generative source of self and society rather than, as social constructionist anthropology might have it, a tabula rasa upon which meanings are inscribed.

At the heart of the article, and through four short essays that address four aspects of ageing and that are informed by four erstwhile relatively discrete fields of anthropological enquiry, I illuminated a locally and generationally shared conceptualisation of the transformation of selfhood through bodily ageing. Bodily ageing may involve experiences of a self that becomes partable, in that it can be experienced as residing elsewhere than in the body with which it had been principally associated (Essay 2). In turn, bodily ageing may involve experiences of having one's lifeworld entered (Essay 3) and, more importantly, of others taking guardianship of one's self (Essay 4). Finally, death may, and commonly is in this context at least, conceptualised as entailing a merging of self with other selves (Essay 4), as symbolised by practices such as the scattering of ashes in shared locations and expressions of 'becoming one'. Importantly also, this inexorable movement of the self from containment in the individual body to communally merged with others is undergirded locally by senses of solidarism born of structures of affect produced by the particular social relations in mining (Essay 1).

In its dispensation as praxis-based anthropology, applied anthropology has often addressed itself to the enactment of change for the betterment of society. Furthermore, a discipline whose raison d'être has consisted of articulating 'the native's point of view' (Geertz 1974), anthropology (and applied anthropology specifically) has proven adept at seeing within the world views of its informants' models for society that, if adopted more broadly, may provide pathways to such betterment (see, for example, Ferguson 2013). However, all too often in anthropological studies of the British working class, the converse has been the case. For example, recent such studies highlighting neo-nationalist sentiment amongst the British working class have contributed to calls within the academic and political Left for recognition of how 'reinvigorated English national identities could be an important resource for constructing a progressive sense of social solidarity and community in England' (Leddy-Owen 2014: 109). Unfortunately, since their corollary is immigration control, these are not sentiments without perils if articulated within a broader political agenda.

Conversely, this article points to ways in which the anthropological study of the older British working class may uncover lived world views with progres- 
sive potential. To reiterate, I have described a locally and generationally shared conceptualisation of the transformation of selfhood through bodily ageing. Though implicit and, by and large expressively inchoate, this feeds into ideas of communitarianism and a lived critique of and resistance against broad-scale processes of individualisation and neoliberalism more generally. In this sense, local older people in Ashington can often be said to age and die radically.

Andrew Dawson is Professor of Anthropology at the University of Melbourne. His published work includes Ageing and Change in Pit Villages of North East England (2010), and in 2017 he won the Australian Anthropological Society Essay Award for 'Driven to Sanity: A Critique of the Senses in Automobilities'. Email: dawsona@unimelb.edu.au

\section{Notes}

1. The real first names are used for all research subjects. Pseudonyms are used for surnames.

2. When spoken about as a political consensus characteristic of post-Second World War Britain, until 1979, this is often referred to alternatively as Butskellism. However, since the Labour Party is usually seen as the political party most closely associated with it, and thus, as the 'natural' party of government in that era, it is more commonly referred to as Labourism.

3. For a comprehensive overview of conceptualisations and definitions of neoliberalism, see Ilana Gershon (2011).

4. The most advanced high school qualification in England.

5. A term commonly used to refer to the Conservative Party.

\section{References}

Alber, E. and H. Drotbohm (eds.) (2015), Anthropological Perspectives on Care: Work, Kinship, and the LifeCourse (New York: Palgrave Macmillan).

Allison, A. (2012), ‘Ordinary Refugees: Social Precarity and Soul in 21st Century Japan', Anthropological Quarterly 85, no. 2: 345-370. doi:10.1353/ anq.2012.0027.

Andrews, E. S. (2017), 'Institutionalising Senile Dementia in 19th-Century Britain', Sociology of
Health and Illness 39, no. 2: 244-257. doi:10.1111/ 1467-9566.12452.

Anzulović, B. (1999), Heavenly Serbia: From Myth to Genocide (New York: New York University Press).

Arnold, M., M. Gibbs, T. Kohn, J. Meese and B. Nansen (2018), Death and Digital Media (London: Routledge).

Beck, U. and Beck-Gernsheim, E. (2002), Individualization: Institutionalized Individualism and its Social and Political Consequences (London: Sage).

Berlant, L. (2007), 'Nearly Utopian, Nearly Normal: Post-Fordist Affect in La Promesse and Rosetta', Public Culture 19, no. 2: 192-211. doi:10.1215/ 08992363-2006-036.

Bloch, M. and J. Parry (1982), Death and the Regeneration of Life (Cambridge: Cambridge University Press).

Buch, E. D. (2013), 'Senses of Care: Embodying Inequality and Sustaining Personhood in the Home Care of Older Adults in Chicago', American Ethnologist 40, no. 4: 637-650. doi:10.1111/amet.12044.

Bulmer, M. (1975), 'Sociological Models of the Mining Community', Sociological Review 23, no. 1: 61-92. doi:10.1111/j.1467-954X.1975.tb00518.x.

Collins, C., G. McCartney and L. Graham (2015), 'Neoliberalism and Health Inequalities', in K. E. Smith, C. Bambra and S. E. Hill (eds.), Health Inequalities: Critical Perspectives (Oxford: Oxford University Press), 124-137.

Csordas, T. J. (1990), 'Embodiment as a Paradigm for Anthropology', Ethnos 18, no. 1: 5-74. doi:10.1525/ eth.1990.18.1.02a00010.

Dawson, A. (1998), 'The Dislocation of Identity: Contestations of "Home Community" in Northern England', in N. Rapport and A. Dawson (eds.), Migrants of Identity: Perceptions of Home in a World of Movement (Oxford: Berg), 61-82.

Dawson, A. (2000), 'The Poetics of Self-Depreciation: Images of Womanhood amongst Elderly Women in an English Former Coal-Mining Town', Anthropological Journal of European Cultures 9, no. 1: 37-51.

Dawson, A. (2002), 'The Mining Community and the Ageing Body', in V. Amit (ed.), Realizing Community: Concepts, Social Relationships and Sentiments (London: Routledge), 21-37.

Dawson, A. (2010), Ageing and Change in Pit Villages of North East England (Melbourne: University of Melbourne Custom Book Centre).

Dawson, A. (2017), 'Driven to Sanity: An Ethnographic Critique of the Senses in Automobilities', The Australian Journal of Anthropology 28, no. 1: 3-20. doi: 10.1111/taja.12168.

Dawson, A. (2018a), 'Youthquake: Neoliberalism and the Ethnicization of Generation', Advances in Anthropology 8, no. 1: 10-17. doi:10.4236/aa.2018.81002. 
Dawson, A. (2018b), 'Hating Immigration and Loving Immigrants: Nationalism, Electoral Politics and the Post-Industrial White Working-Class in Britain', Anthropological Notebooks 24, no. 1: 5-21. http://www .drustvoantropologov.si/pregled_letnikov_eng.html.

Dawson, A. and B. Goodwin-Hawkins (2018a), 'Moralities of Care in Later Life', Australian Journal of Anthropology 29, no. 2: 141-145.

Dawson, A. and B. Goodwin-Hawkins (2018b), PostFordist Death: A Comparative Ethnographic Analysis, Death Studies 42, no. 5: 282-289. doi:10.1080/0748 1187.2017.1396397.

Dawson, A. and B. Goodwin-Hawkins (2018c), 'Going with the Flow of Dementia: A Reply to Nigel Rapport on the Social Ethics of Care', Australian Journal of Anthropology 29, no. 2: 258-262.

Dawson, M. (2012), 'Reviewing the Critique of Individualization', Acta Sociologica 55, no. 4: 305-319. doi:10.1177/0001699312447634.

De Beauvoir, S. (1972) Old Age (London: Deutsch, Weidenfeld and Nicolson).

Devereux, G. (1978), Ethnopsychoanalysis: Psychoanalysis and Anthropology as Contemporary Frames of Reference (Berkeley: University of California Press).

Etzioni, A. (1996), The New Golden Rule (London: Basic Books).

Evans, G. (2012), "“The Aboriginal People of England”: The Culture of Class Politics in Contemporary Britain', Focaal - Journal of Global and Historical Anthropology 62, no. 1: 17-29. doi:10.1017/S00267 49X14000018.

Ferguson, J. (2013) 'Cosmologies of Welfare: Two Conceptions of Social Assistance in South Africa', in F. Aulino, M. Goheen and S. J. Tambiah (eds.), Radical Egalitarianism: Local Realities, Global Relations (New York: Fordham University Press), 111-118.

Geertz, C. (1974), "“From the Native's Point of View": On the Nature of Anthropological Understanding', Bulletin of the American Academy of Arts and Sciences 28, no. 1: 26-45. doi:10.2307/3822971.

Gershon, I. (2011), 'Neoliberal Agency', Current Anthropology 52, no. 4: 537-555. doi:10.1086/660866.

Giddens, A. (1991), Modernity and Self-Identity: Self and Society in the Late Modern Age (Cambridge: Polity).

Goodwin-Hawkins, B. and A. Dawson (2018), 'Life's End: Ethnographic Perspectives', Death Studies 42, no. 5: 269-274. doi:10.1080/07481187.2017.1396394.

Gramsci, A. (1971), Selections from the Prison Notebooks, trans. Q. Hoare and G. N. Smith (New York: International Publishers).

Green, J. A. (2008), Beyond the Good Death: The Anthropological Study of Modern Dying (Philadelphia: University of Pennsylvania Press).
Grøn, L. and C. Mattingly (2018), 'In Search of the Good Old Life: Ontological Breakdown and Responsive Hope at the Margins of Life', Death Studies 42, no. 5: 306-313. doi:10.1080/07481187.2017.1396394.

Hertz, R. (1960), Death and the Right Hand (Glencoe, IL: The Free Press).

Kitwood, T. (1997), Dementia Reconsidered: The Person Comes First (Milton Keynes, UK: Open University Press).

Kleinman, A. (2013), 'From Illness as Culture to Caregiving as Moral Experience', New England Journal of Medicine 368, no. 15: 1376-1377. doi:10.1056/ NEJMp1300678.

Latimer, J. E. (2018), 'Repelling Neoliberal WorldMaking? How the Ageing-Dementia Relation Is Reassembling the Social', Sociological Review 66, no. 4: 832-856. doi:10.1177/0038026118777422.

Leddy-Owen, C. (2014), 'Reimagining Englishness: "Race", Class, Progressive English Identities and Disrupted English Communities', Sociological Review 53, no. 4: 109-128.

Leder, D. (1990), The Absent Body (Chicago: University of Chicago Press).

Lock, M. (2014), The Alzheimer Conundrum: Entanglements of Dementia and Ageing (Princeton, NJ: Princeton University Press).

Macdonald, G. (2018), 'Death in Life or Life in Death? Dementia's Ontological Challenge', Death Studies 42, no. 5: 290-297. doi:10.1080/07481187.2017.1396398.

Miller, R. L. and J. Brewer (2003) 'Biographical Method', in R. L. Miller and J. Brewer (eds.), The A-Z of Social Research (London: Sage), 15-18.

Moser, I. (2011), 'Dementia and the Limits of Life: Anthropological Sensibilities: STS Interferences, and Possibilities for Action in Care', Science, Technology and Human Values 36, no. 5: 704-722. doi:10.1177/0162243910396349.

Muehlebach, A. and N. Shoshan (2012), 'Post-Fordist Affect: Introduction', Anthropological Quarterly 85, no. 2: 317-344. doi:10.14506/ca29.1.04.

Newby, H. (1979), The Deferential Worker: A Study of Farm Workers in East Anglia (Madison, WI: University of Wisconsin Press).

Rudman, D. L. (2015), 'Embodying Positive Ageing and Neoliberal Rationality: Talking about the Ageing Body with Narratives of Retirement', Journal of Aging Studies 34, no. 1: 10-20. doi:10.1016/j.jaging .2015.03.005.

Shostak, M. (1981), Nisa: The Life and Words of a Kung Woman (Cambridge, MA: Harvard University Press).

Taussig, M. (1999), Defacement: Public Secrecy and the Labour of the Negative (Stanford, CA: Stanford University Press). 
Thelen, T. and C. Coe (2017), 'Political Belonging through Elderly Care: Temporality, Representations and Mutuality', Anthropological Theory. doi:10.1177/1463499617742833.

Walter, T. (2004), 'Historical and Cultural Variants on the Good Death', British Medical Journal 327, no. 7408: 218-220. doi:10.1136/bmj.327.7408.218.
Wansbeck Council (1995), Guide Around: A Guide to Amenities for the Active Elderly (Morpeth, UK: Wansbeck Council).

Williamson, B. (1982), Class, Culture and Community: A Biographical Study of Social Change in Mining (London: Routledge). 